\title{
Bioecological features of coccinellide in the southern Kashkadarya province, Uzbekistan
}

\author{
Khurshida Burieva ${ }^{1 *}$, Gulnara Mirzaeva ${ }^{1}$, Nodira Arabova ${ }^{2}$, and Makhmuda \\ Mansurkhodjaeva ${ }^{1}$ \\ ${ }^{1}$ Institute of Zoology, Academy Sciences of Uzbekistan, Tashkent, Uzbekistan \\ ${ }^{2}$ Tashkent State Agrarian University, 100140, Tashkent province, Uzbekistan
}

\begin{abstract}
This research was conducted in 2019-2020 in the northern and southern administrative districts of the southern Kashkadarya province of Uzbekistan. This study on the distribution of coccinellides in agrobiocenoses has been conducted at different experimental periods. In the agrobiocenoses of Kashkadarya province, 5 subspecies of coccinellides (Scymninae, Chilocorinae, Coccidulinae, Epilachninae, and Coccinellinae), 8 tribes, and 31 species belonging to 22 genera were found. Experiments have shown that species belonging to the genera Chilocorus (Leach, 1875) are relatively rare species and are not considered specific species for cotton agrocenosis. Coccinella septempunctata was observed as the most common species. The eggs of Coccinella septempunctata were studied separately in this research. Wintering conditions in mountainous areas were also considered and particular attention was paid to the beneficial entomophagous species of coccinellides.
\end{abstract}

\section{Introduction}

In particular, the damage caused by pests has theoretical and practical significance. Although the chemical method of pest and other arthropod control is widely used in the world, such insecticides are not sufficiently selective and effective [1]. According to the latest data, 428 species of arthropods on earth have become resistant to various groups of pesticides, 260 of which are pests of agricultural crops [2]. In addition, chemical control has its drawbacks with its significant negative impact on the environment, plant quality and living organisms. Natural entophagous species - coccinellides - are especially important in the fight against plant lice (Homoptera and Aphidoidea) in agriculture. The study of the composition, number dynamics and interactions of biological species belonging to different taxonomic groups in agrocenoses is of great theoretical and practical importance in planning and effective organization of biological control measures against crop pests in agriculture, which in turn achieves optimal yields [3]. In this regard, the seasonal number dynamics of coccinellide species in agrocenoses in the Central Asian region, the density of distribution across the area and the factors influencing these indicators have not been fully studied [3, 4]. Also, although the prospects for its use are highly valued, at present in the

* Corresponding author: khurshida.burieva@yandex.ru 
agricultural practice of Uzbekistan on coccinellide species are almost not used for biological control of pests. Many coccinellide species are potential entomophagous species in the imago and larval stages and occupy secondary positions in the trophic chain $[5,6]$. Coccinellides are crustaceans of significant economic importance and are involved in the population control of some insect species, as well as food for a number of entamophagous species [7, 8]. Studies (California) have reported that the Hippodamia convergens species is effective as an entomophagous against agricultural pests. Introduced in the United States: Rodolia cardinalis (Mulsant, 1850); introduced from Europe in North and South America: Coccinella septempunctata (Linnaeus, 1758), Adalia bipunctata (Linnaeus, 1758), and Chilocorus bipustulatus (Lin5e); introduced from Australia: Harmonia axyridis (Pallas, 1773) - synonym: Leis axyridis Pallas; introduced in Abkhazia from Australia: $R$. cardinalis and Cryptolaemus montrouzieri (Mulsant, 1850); and, introduced from Assyria: Chornocorus (Chilocorus) species have been tested for biological control of agricultural pests and positive results have been reported [9-13].

\section{Materials and methods}

Kashkadarya province is located in the south-west of Uzbekistan, in the Kashkadarya basin, on the western edge of the Pamir-Alay mountain system, between the Amudarya and Zarafshan rivers, Gissar and Zarafshan ridges [14]. It is bordered by Bukhara to the northwest, Surkhandarya to the southeast, Turkmenistan to the southwest and west, Tajikistan and Samarkand to the east. Kashkadarya province has 667,600 hectares of arable land, of which 418,700 hectares are irrigated. Cotton is planted on 173,800 hectares, grain on 205,000 hectares, vegetables on 3,200 hectares, melons on 2,000 hectares, potatoes on 500 hectares, and fodder crops on 38,100 hectares. 32,800 hectares of land are occupied by perennial trees, of which 13,200 hectares are orchards, 9,200 hectares are mulberries, and 10,400 hectares are vineyards. As we can see, Kashkadarya province is one of the most important regions with its agricultural products.

The climatic conditions in the study area are moderate, with an average of $+27 \ldots+31$ ${ }^{\circ} \mathrm{C}$ in some areas with fluctuations in the range of $+38 \ldots+41{ }^{\circ} \mathrm{C}$, and relative humidity on average from $26-28 \%$ in some areas to $15-17 \%$ [14].

Collection of coccinellide (Coleoptera and Coccinellideae) species distributed in the study area in the imago phase was carried out during March-September 2019-2020 using an entomological handle. Eggs, larvae and fungi of coccinellide species were also collected from the study area by hand. In the biotopes of the study area, biological material was collected from the bark of growing trees, shores, small rocky gravel plots in the winter reservation zone, which belongs to the middle mountain region, and materials in the form of photo evidence were collected during the collection. In the study, the collection of coccinellide species, the calculation of the distribution density in biotopes was carried out on the basis of a standard method, using an entomological handle, by the method of spraying. In cotton agrobiocenoses and adjacent biotopes, the process of collecting coccinellide species was carried out in a strict order, between 1000-1200 hours per day, between 1600-1800 hours, once every 5 days. The study areas were divided into $25200 \times$ $200 \mathrm{~cm}\left(2 \mathrm{~m}^{2}\right)$ surface areas in each biotope using nylon yarn.

Of the collected species, the dominant species were calculated based on the following equation (1):

$$
\mathrm{D}=\mathrm{k} / \mathrm{K} \times 100
$$

where, D - dominant species, $\mathrm{k}$ - number of all biological species in the collected test specimens, and $\mathrm{K}$ - total number of individual species. 
The research methods of VV Yakhontov and KK Fasulati, FR Khakimov were used in this study $[11,12]$. The method of phenological observations was used in the research. The egg-laying rate of coccinellides was determined using a standard method. The object of study was fixed in $70 \%$ ethanol solution for analysis of morphometric parameters. The process of feeding coccinellides with plant sap was studied under a magnification of two to eight times using the MB-10 binocular (Russia). The experiments were performed 3-4 times in repetitions $(n=3-4)$. The air temperature in the study area was measured using a standard thermometer and the relative humidity of the air using a barometer. Species composition of samples of Chilocorini (Mulsant, 1846) tribe species collected from agrocenoses and adjacent zones was analyzed using MYuS-10 binoculars.

Cotton agrocenosis and adjacent bedrock agrocenosis, wheat agrocenosis and weed growing plots were selected for the study. 100 model plant tufts of 0.5 ha of cotton agrobiocenosis were identified and separated by a paper label. The number of plant lice, spider mites, and coccinellide species in replicated plant bushes 2 times per week was studied using a method developed by FM Uspensky $[11,12]$.

\section{Results and discussion}

As a result of research in agrobiocenoses of Kasbi and Mirishkor administrative districts of Kashkadarya province, 5 subspecies of coccinellides (Scymninae, Chilocorinae, Coccidulinae, Epilachninae, and Coccinellinae), 8 tribes, and 31 species belonging to 22 genera were identified [11] (Table 1).

Table 1. Coccinellide species in agrobiocenoses of Kashkadarya province.

\begin{tabular}{|c|c|c|c|}
\hline $\begin{array}{c}\text { Newly founded } \\
\text { family }\end{array}$ & Tribe & Genera & Species \\
\hline \multirow{2}{*}{$\begin{array}{c}\text { Scymninae } \\
\text { (Mulsant, 1846) }\end{array}$} & $\begin{array}{c}\text { Stethorini } \\
\text { (Dobrzhanskiy, } \\
1925)\end{array}$ & $\begin{array}{l}\text { Stethorus (Weise, } \\
1885 \text { ) }\end{array}$ & Stethorus pusillus (Herbst, 1797) \\
\hline & $\begin{array}{c}\text { Hyperaspini } \\
\text { (Mulsant, 1846) }\end{array}$ & $\begin{array}{c}\text { Hyperaspis } \\
\text { (Dejean, 1835) }\end{array}$ & $\begin{array}{c}\text { Hyperaspis transversoguttata } \\
\text { (Weise, 1878) }\end{array}$ \\
\hline \multirow{4}{*}{$\begin{array}{l}\text { Chilocorinae } \\
\text { (Mulsant, 1846) }\end{array}$} & $\begin{array}{c}\text { Platynaspini } \\
\text { (Mulsant, 1846) }\end{array}$ & $\begin{array}{c}\text { Platynaspis } \\
\text { (Redtenbacher, } \\
\text { 1843) } \\
\end{array}$ & $\begin{array}{l}\text { Platynaspis luteorubra (Goeze, } \\
\text { 1777) }\end{array}$ \\
\hline & \multirow{3}{*}{$\begin{array}{c}\text { Chilocorini } \\
\text { (Mulsant, 1846) }\end{array}$} & $\begin{array}{c}\text { Exochomus } \\
\text { (Redtenbacher, } \\
1843 \text { ) } \\
\end{array}$ & $\begin{array}{c}\text { Exochomus octosignatus (Gebler, } \\
1830 \text { ) }\end{array}$ \\
\hline & & $\begin{array}{c}\text { Parexochomus } \\
\text { (Barovsky, 1922) }\end{array}$ & $\begin{array}{c}\text { Parexochomus melanocephalus } \\
\text { (Zubkov, 1833) }\end{array}$ \\
\hline & & $\begin{array}{c}\text { Chilocorus (Leach, } \\
1815 \text { ) } \\
\end{array}$ & $\begin{array}{c}\text { Chilocorus kuwanae (Silvestri, } \\
1909 \text { ) }\end{array}$ \\
\hline $\begin{array}{l}\text { Coccidulinae } \\
\text { (Mulsant, 1846) }\end{array}$ & $\begin{array}{c}\text { Coccidulini } \\
\text { (Mulsant, 1846) }\end{array}$ & $\begin{array}{c}\text { Coccidula } \\
\text { (Kugelann, 1798) }\end{array}$ & $\begin{array}{l}\text { Coccidula rufa } \\
\text { (Herbst, 1783) }\end{array}$ \\
\hline \multirow{6}{*}{$\begin{array}{l}\text { Coccinellinae } \\
\text { (Latr., 1807) }\end{array}$} & \multirow{6}{*}{$\begin{array}{c}\text { Halyziini } \\
\text { (Mulsant, 1846) }\end{array}$} & $\begin{array}{c}\text { Psyllobora } \\
\text { (Dejean, 1835) }\end{array}$ & $\begin{array}{c}\text { Psyllobora vigintiduopunctata } \\
\text { (Linnaeus, 1758) }\end{array}$ \\
\hline & & $\begin{array}{c}\text { Bulaea (Mulsant, } \\
1850) \\
\end{array}$ & $\begin{array}{l}\text { Bulaea lichatschovi } \\
\text { (Hummel, 1827) }\end{array}$ \\
\hline & & \multirow{2}{*}{$\begin{array}{c}\text { Coccinula } \\
\text { (Dobzhansky, 1925) }\end{array}$} & $\begin{array}{c}\text { Coccinula quatuordecimpustulata } \\
\text { (Linnaeus, 1758) }\end{array}$ \\
\hline & & & $\begin{array}{c}\text { Coccinula sinuatomarginata } \\
\text { (Faldermann, 1837) }\end{array}$ \\
\hline & & \multirow{2}{*}{$\begin{array}{l}\text { Tytthaspis (Crotch, } \\
1874)\end{array}$} & $\begin{array}{l}\text { Tytthaspis sedecimpunctata } \\
\text { (Linnaeus, 1761) }\end{array}$ \\
\hline & & & $\begin{array}{c}\text { Tytthaspis gebleri (Mulsant, } \\
1850)\end{array}$ \\
\hline
\end{tabular}




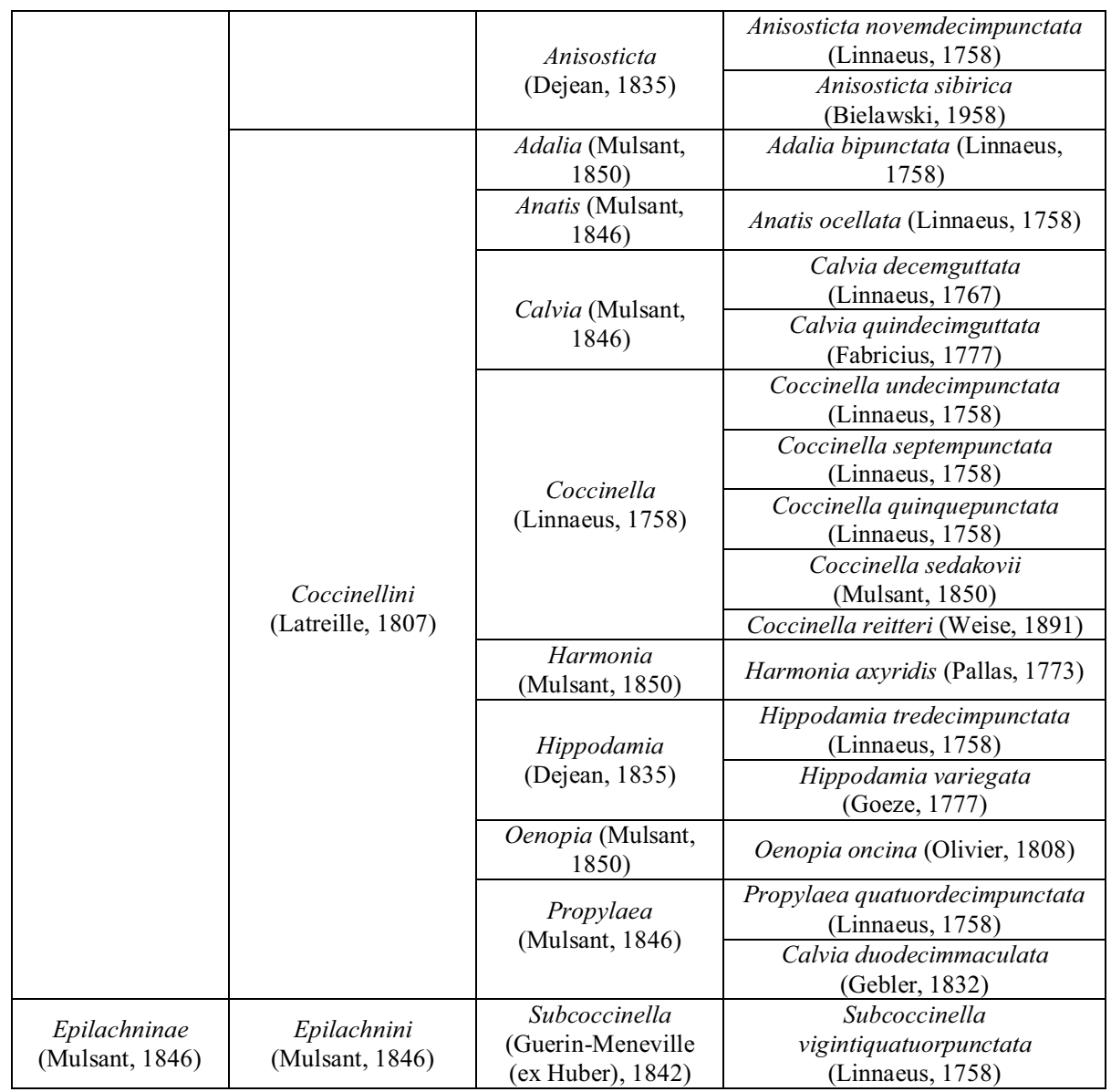

For the first time in the Kashkadarya province of Uzbekistan, where the study was conducted, the state of wintering was studied. The study found that the seven-point coccinella (Coccinella septempunetata), which is the dominant species in the studied biotopes, including cotton agrocenoses, is the most common. The body of the beetle is round-oval, strongly bulging, almost hemispherical, often dotted, the top is not covered with hairs. The upper part of the wing is red, with 7 black dots, and body length 5-8 mm.

Coccinella septempunetata is common in the Palearctic. It is found in all regions of Europe, North Africa (except Macronesia, the Azores and the Sahara), Asia, the CIS countris, and everywhere in Uzbekistan. The Coccinella septempunetata species was found to overwinter in the mid-mountainous region at an altitude of 2,200-2,250 m above sea level, at a distance of approximately 1000-1500 m from the study area. In the winter zone, the seven-pointed coccinella (Coccinella septempunetata) species has been reported to form 54-117 clusters among small rocks/gravels. The hibernation of seven-spotted beetles lasts for some time, beginning in June and ending in late October.

Coccinella septempunctata has been observed to overwinter in a variety of conditions on plains, under rocks, haze, among plants and shrubs, in soil cracks, and sometimes even under tree bark. The diversity of such wintering species of Coccinella septempunctata is the result of the high ecological adaptability of the species. This allows it to spread widely and in a variety of conditions. Alternatively, the Coccinella septempunctata species is often typical and has developed the ability to overwinter in clusters. There are also atypical wintering features. However, it should be noted that unfavorable weather conditions, as 
well as the spread of fungal diseases among wintering beetles of this species, lead to mass extinction of the main wintering type populations. However, some populations of this species have not been able to survive the wintering period under normal conditions, ensuring that the number of species soon recovers, for example, under the bark of trees, in the hollow, under the rocks of fallen leaves, and bushes and grass remnants (Fig. 1).

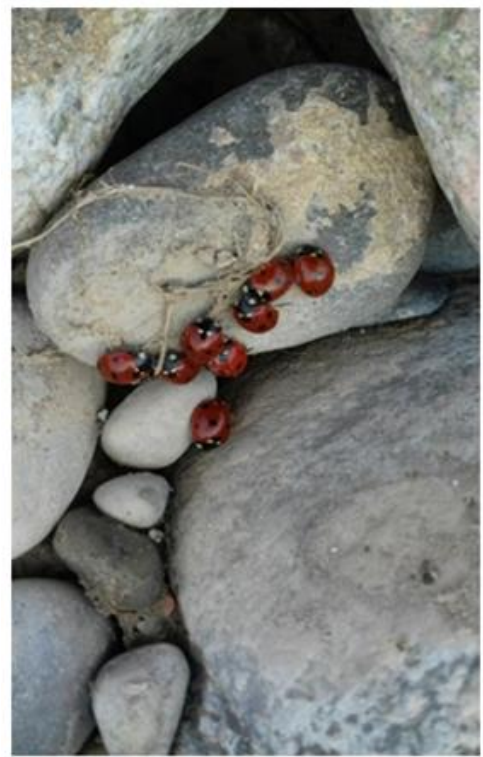

A

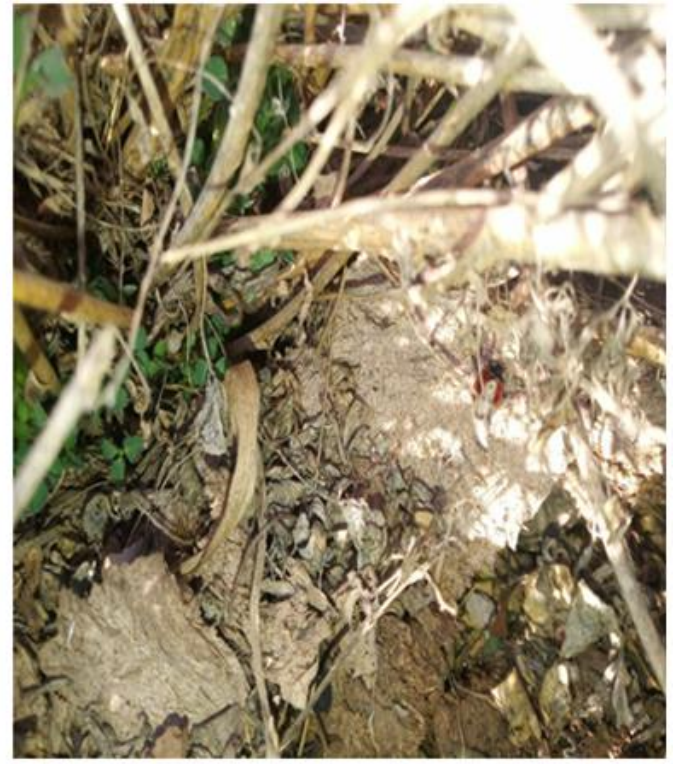

B

Fig. 1. A. Wintering of Coccinella septempunetata under small gravel, and B. Wintering of Coccinella septempunetata under plant roots.

Due to the hot and dry climate in the Kashkadarya province, coccenillide species were found to enter the active phase in the second decade of March (March 12-18, 2020). The process of laying eggs was observed in the species of seven-pointed beetle (Coccinella septempunctata) on March 17-18, 2020 (Fig. 2). The eggs are light yellow in color and lay 31 to 51.68 eggs when hatched. It lays its eggs mainly in the light. Dark-colored larvae were recorded from the eggs of the seven-spotted beetle (Coccinella septempunctata).

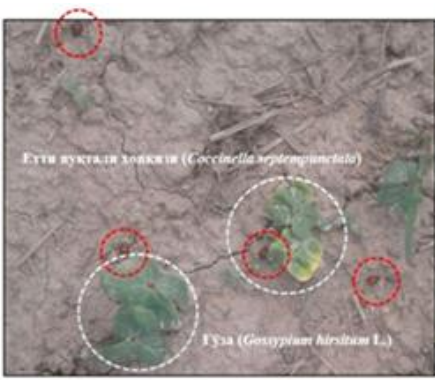

A

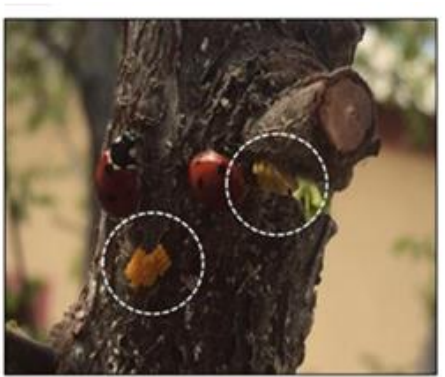

B

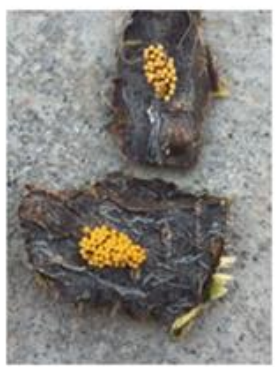

$\mathrm{C}$

Fig. 2. A. Distribution status of coccinellides in cotton agrocenosis; B. Process of laying eggs in the bark of a tree; and, C. Eggs of Coccinella septempunetata.

The larvae that hatch from the eggs are initially fed by absorbing the remains of the eggs, unripe eggs, aphids and other body fluids of the larvae. The larvae hatch three times 
and move to the fourth age, and this period is 13-16 days. The larval stage progresses to a 24-hour pre-mushroom period in the final stage. During this period, it was observed that the larvae become inactive without feeding at all. The body shape also changes and becomes slightly compressed and curved. It has been observed that it takes 25-30 days if one feed is enough for one generation to reach the full imago stage.

It was noted that the observed air temperature and relative humidity did not significantly affect the life cycle, activity of the species Seven-pointed beetle (Coccinella septempunctata). It was hypothesized that the object of study could be identified as a biological species highly adapted to xerophilous conditions. Also, in cotton agrobiocenoses, after harvesting, during the autumn months (Sep 10 and Oct 15 2020), a species of sevenspotted beetle (Coccinella septempunetata) was also encountered. A case of cannibalism was observed among Coccinella septempunetata. Although the seven-spotted beetle reproduces 3 times, its third generation has only been noted to be specific to certain populations of the beetle. This species is a broad polyphagous, found in apple lice (Aphis pomi Geer: Disaphis mali Geer: D affinus Mordw), lice species in pears (Hyalopterus pruni Geeff: Myzodes percicae Subz) and in legumes (Aphis fabae Scop), cereals (Brachycaudus poxius), fertilizers on cotton (Aphiscroccivora Koch; A gossypil Glov) as well as dozens of other species of lice found in other cultivated and wild plants. Surveys in Mirishkor and Nishan administrative districts of Kashkadarya province revealed the prevalence of coccinellides in the territory of farms "Galaba" and "Nishon Kurki". Coccinellide species were generally observed to be relatively active and fed between 9-12 and 14-19 h of the day. Studies have shown that in cotton agrocenoses, coccinellide species feed on eggs and larvae of pests, which in turn reduces coccinellide species in cotton pest control by $50-60 \%$, as well as in field conditions where the entomophag/phytophage ratio is 1:25 to $90-95$ reduction was found [2]. It is also recommended to reduce the use of chemicals in agriculture in order to protect the population of coccinellides in the area of cotton agrocenoses, to prevent the burning of plant residues after harvest in winter zones [2].

The study found that a total of 9 coccinellide species (based on a total of 436 collected biological samples) were distributed in the biotopes of the region. The dominant species in the biotopes are the seven-pointed coccinella (Coccinella septempunctata) and the elevenpointed coccinella (Coccinella undecimpunctata). The results obtained are consistent with the available literature data. In particular, 12-15 coccinellide species (Coccinella septempunetata, Syngarmonia conglobata, Propyleae quatuordeeimpunetata, Adalia bipunetata, Adonia variegata, Chilocorus bipustulatus, Scyihtius bunilos as turilus, and Scyihtius bunvct) were identified in the study in Central Asia (Tajikistan) and seven-dot dot and variable dot types have been recorded [1]. Coccinella septempunctata and Adonia variegata, which are widespread in agrocenoses, were recorded as eurybiont species [1]. Studies have also shown that the coccinellide species Syngarmonia conglobata, Propyleae quatuordeeimpunetata, Adalia bipunetata, and Adonia variegata overwinter under the bark of poplar (Populus pyramidalis) [1].

Some researchers have found that in agrobiocenoses in Central Asian climates, Coccinella septempunetata and Chilocorus bipustulatus species do not migrate to the full wintering zone, with an average of 6-35 per $1 \mathrm{~m}^{2}$ [1]. Typically, coccinellide species are poikilothermic insects, which become active in the Central Asian climate in early spring (late February, early April) at a temperature of $+8 \ldots+10^{\circ} \mathrm{C}$. Also, the full activation of coccinellide species in the winter zone was observed in late April, early May, as the air temperature in the middle mountain region was below the average $+8{ }^{\circ} \mathrm{C}$ at this time [1].

Eleven-pointed beetle (Coccinella undecimpunctata) was also recorded as a dominant species in the study area. The body is elongated-oval, moderately convex, often dotted, not covered with hairs, the upper part of the wing is brownish-yellow, the forefoot is black; the general has a wide wavy border. The length of the body is $3.5-5 \mathrm{~mm}$. This species is 
widespread throughout Europe, Asia, North Africa, the CIS and Uzbekistan, except the Palearctic. Although this species is widespread, it is mainly xerophilous in open forest areas, agricultural areas, and is also common in deserts and semi-deserts.

In our research, we found that fruit trees (apples, peaches, apricots, pears, plums, almonds, and walnuts), willows, poplars, spruces, shrubs, as well as rosehip, hawthorn is more common. Fruit trees, grasses, cotton lice clusters, and grain plants were collected in large numbers. In addition to the plant lice found in the above-mentioned plants, the elevenspotted beetle and larvae also feed on plant flower nectar (Fig. 3). The eleven-pointed beetle develops by breeding twice a year. Beetles overwinter mainly in the mountains, and partly beetle populations have also been found to overwinter in the plains.
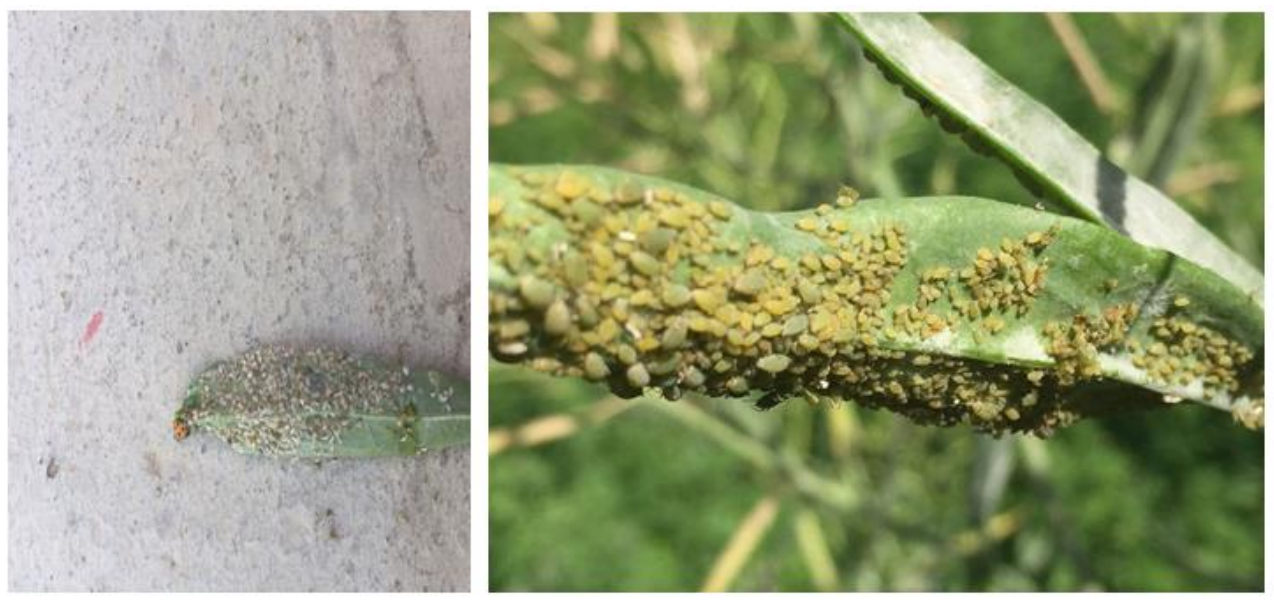

Fig. 3. Process of feeding on the aphids of the eleven-pointed beetle (Coccinella undecimpunctata).

Images of species belonging to the genus Chilocorus (Leach, 1815) are morphoanatomically the upper part of the upper wings is smooth, dark reddish color, relatively sharp convexity, the anterior part of the body is round, the sides are slightly curved, the head segment is relatively large, in males the abdomen has 5 segments and characterized by the presence of 6 in female individuals. Also in the study, the species of the genus Chilocorus (Leach, 1815) have a heterogeneous description in terms of morphoanatomical traits, and it is recommended by some researchers to divide them into smaller taxonomic groups (Table 2).

Table 2. Quantitative analysis of species of the genus Chilocorus (Leach, 1815) identified in the study area.

\begin{tabular}{|c|c|c|c|c|c|}
\hline \multirow[b]{2}{*}{ \# } & \multirow[b]{2}{*}{ Species } & \multicolumn{4}{|c|}{ Types of biotopes } \\
\hline & & 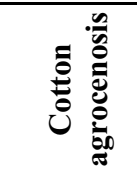 & 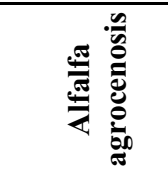 & 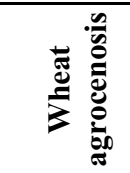 & $\overbrace{z}^{\infty}$ \\
\hline 1 & $\begin{array}{l}\text { Chilocoruskuwanae } \\
\text { (Silvestri, 1909) }\end{array}$ & $\begin{array}{c}\text { imago } \\
\left(20^{\Uparrow} ; 49\right)\end{array}$ & & & $\begin{array}{c}\text { imago } \\
\left(11 \delta^{\lambda} ; 8+\right)\end{array}$ \\
\hline 2 & $\begin{array}{l}\text { Chilocorus bipustulatus } \\
\text { (Linnaeus, 1758) }\end{array}$ & & imago $(3 \overbrace{}^{\lambda})$ & & $\begin{array}{l}\text { Imago } \\
\left(60^{\top} ;\right. \\
13+) \\
\end{array}$ \\
\hline 3 & $\begin{array}{l}\text { Chilocorus geminus } \\
\text { (Zaslavskij, 1962) }\end{array}$ & & imago (7q) & 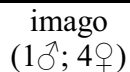 & $\begin{array}{c}\text { imago } \\
(2+)\end{array}$ \\
\hline
\end{tabular}


Chilocorus (Leach, 1815) is a rare species in the study area, with a total of 3 species (Chilocoruskuwanae (Silvestri, 1909); Chilocorus bipustulatus (Linnaeus, 1758); and, Chilocorus geminus (Zaslavskij, 1962)).

Some researchers have studied the ecological characteristics of coccinellide species in agrocenoses in the Italian region, their importance as entomophagous. The analysis of the ecological characteristics of the populations of insect species directly determines the possibility of their use in agriculture to regulate the dynamics of the number of pest species.

One of the main pest species in cotton agrobiocenoses is the spider (Tefcranichus urticae Koch) migration, the average is $9-16$ pieces per 1 cotton stalk, the maximum value of this indicator on Apr 15-20 - 14-27 pieces. It was also found that at this time in some individual cotton bushes the damage was up to 456 per 100 leaves.

Plant lice - mass migration to cotton agrobiocenoses after overwintering in weed cover in the period from March 5-10 to Apr 5-10, during which time the number of infected cotton stalks is 15-24, the maximum increase in May 10-15, was found to be 54-123 grains relative to the cotton stalk. It is also estimated that the number of cotton lice in the study area will decrease from August 20-25, which may be related to migration towards weed cover. Plant lice (Homoptera and Aphididae) are pest insects that live in a colony-type, small-sized, oral-sucking type, leaving up to 20 offspring per year. Plant lice (Aphis craccivora Koch), melon crops or cotton lice (Aphis gossypii Glov), and large lice of cotton (Acyrthosiphon gossypii Mordv) cause deformation/shedding of leaves in cotton plants, which in turn leads to a sharp decrease in yield Grots. plant lice typically overwinter in the fertilized egg phase in bedrock, larvae emerge in early spring (mid-March), and migrate to cotton agrocenoses in the imago phase in early May [12].

Cotton large lice (Acyrthosiphon gossypii Mordv) - larvae and wingless females overwinter in the imago stage $(1=0.3-3.5 \mathrm{~mm})$, emerge from the wintering stage in March, the imago stage is formed in early May, in more than 100 plant species in the colony type pest has been identified and reproduces parthenogenetically, leaving more than 20 offspring per year. Acyrthosiphon gossypii Mordv. type is located on the stems and horns, leaves, bark of cotton, overwinters in the fertilized egg stage in the cotton stalks and surrounding weeds [11]. The bioecology of plant lice in Uzbekistan has been studied by a number of researchers. One of the most pressing issues in agriculture is the development and implementation of environmentally friendly methods of pest control. During the study, the number of plant lice, spider mites and coccinellide species in 100 model plant tufts identified in cotton agrobiocenosis was studied 2 times per week. In the study area, cotton seeds were sown between April 4-10, the first germination took place after 10-14 days, grazing developed between May 5 and June 10 (up to a maximum of 18 per 1 plant bush). It has been observed during experiments that coccinellide species have the property of hemolymph synthesis with toxic effects against cousins. The larvae of many coccinellide species are hairy on the outside, which is a mechanism of protection against ultraviolet radiation, excess water loss, as well as morphological adaptation to parasites. Some researchers have analyzed the role of the outer hair cover of larvae in the species Scymnus nubilus Mulsant in protection against parasitic species [5]. It has also been found that 1 Coccinella septempunctata L. kills up to 200 cabbage lice (Brevicoryne brassicae L. (Aphididae)) per day [7]. While coccinellide species are beneficial entomophagous in agriculture, some species are also listed as harmful species. In particular, some researchers have found that the high degree of flexibility of the Harmonia axyridis Pallas species leads to a reduction in the range of other species [3]. It has also been reported that the Harmonia axyridis Pallas species causes significant damage to vineyards in agriculture [7]. Thus, coccinellides are one of the important components in natural ecosystems and are involved in the regulation of the number of pests such as larvae of leafy insects, spiders, plant lice and nematodes in agrocenoses and forest biocenoses [9]. 


\section{Conclusions}

In the studied biotopes, including the cotton agrocenoses, the dominant species, the sevenpointed coccinella (Coccinella septempunetata), wintered in the mid-mountainous region at an altitude of 2,200-2,250 m above sea level, approximately 1,000-1,500 m from the study area. In the winter zone, the seven-pointed coccinella (Coccinella septempunetata) species has been reported to form 54-117 clusters among small rocks/gravels.

In turn, coccinellide species have been found to reduce cotton lice by $50-60 \%$ in pest control, as well as by $90-95 \%$ in field conditions where the entomophag/phytophag ratio is $1: 25$.

The analysis of the ecological characteristics of the populations of insect species directly determines the possibility of their use in agriculture in regulating the quantitative dynamics of pest species.

Although the eleven-pointed beetle (Coccinella undecimpunctata) is a common species, it is mainly found in open areas of forests, agricultural areas are xerophilous, and is also common in deserts and semi-deserts.

The incidence rate of Chilocoruskuwanae (Silvestri, 1909), Chilocorus bipustulatus (Linnaeus, 1758) and Chilocorus geminus (Zaslavskij, 1962) in the study area was 40.9; 36.1 ; and, $22.9 \%$, respectively.

\section{References}

1. F.R. Khakimov, Eurasian Entomol. Journal, 18(2), 79-83 (2019)

2. M. Urmanova, A. Kuziev, D. Burkhanova, D. Kadirova, N. Namozov, N. Shadieva, E3S Web of Conferences, 244, 02036 (2021)

3. A. Biranvand, O. Nedved, W. Tomaszewska, C. Canepari, J. Shakarami, L. Fekrat, M. Khormizi, ZooKeys, 587, 37-48 (2016)

4. S. Islamov, N. Namozov, M. Saidova, D. Kodirova, E3S Web of Conferences, 244, 03028 (2021)

5. V.F. Khabibullin, O.S. Muravitskiy, Materials on flora and fauna of the Republic of Bashkortostan, 5, 21-24 (2014)

6. N. Namozov, M. Tursinbaev, I. Yuldoshev, S. Yuldasheva, E3S Web of Conferences, 244, 02007 (2021)

7. N.Ch. Namozov, D.A. Kodirova, M.I. Usmonova, International journal of scientific \& technology research, 9(03), 5491-5493 (2020)

8. R.A. Kulmatov, A.A. Kist, IND. LAB, 44(12), 1689-1692 (1978)

9. D.A. Romanov, Russian Journal of Biological Invasions, 4, 65-86 (2018)

10. V.M. Emets, R.A. Kulmatov, Doklady Biological Sciences, 271(1-6), 370-372 (1983)

11. Kh. P. Burieva, G.S. Mirzaeva, Bulletin of Khorezm Mamun Academy, 12, 13-16 (2020)

12. Kh.P. Burieva, G.S. Mirzaeva, Scientific Bulletin of Namangan State University, 12, 187-192 (2020)

13. B. Abdullaev, R.A. Kulmatov, A.A. Kist, Industrial Laboratory (USSR) (English translation of Zavodskaya Laboratoriya), 54(7), 710-713 (1989)

14. A. Jumanov, S. Khasanov, A. Tabayev, G. Goziev, U. Uzbekov, E. Malikov, IOP Conference Series: Earth and Environmental Science, 614(1), 012150 (2020) 